\title{
Interaction of a standardized mistletoe (Viscum album) preparation with antitumor effects of Trastuzumab in vitro
}

\author{
U. Weissenstein ${ }^{1 *}$ D, M. Kunz ${ }^{1}$, K. Urech', U. Regueiro ${ }^{1}$ and S. Baumgartner ${ }^{1,2}$
}

\begin{abstract}
Background: Besides conventional anticancer therapy many breast cancer patients use complementary and alternative medicine (CAM) like the medicinal herb mistletoe (Viscum album L.). To gain more knowledge about possible herb-drug interactions between CAM and conventional anticancer medications, in the present in vitro study we investigated the effect of a standardized mistletoe preparation on the action of Trastuzumab, a drug used for the treatment of Her-2 positive breast cancer.

Methods: The Her-2 positive human breast carcinoma cell line SK-BR-3 was treated with Trastuzumab. Different doses of the drug were combined with Viscum album extract (VAE) in clinically relevant doses. Proliferation, apoptosis, cell cycle and the secretion of vascular endothelial growth factor (VEGF) were analyzed.

Results: No inhibition of antitumor efficacy of Trastuzumab by VAE was detected. VAE and Trastuzumab, either alone or in combination, inhibited proliferation of SK-BR-3 cells in vitro. At higher concentrations VAE induced apoptosis, which was not observed for Trastuzumab. Cells treated with Trastuzumab underwent a G0/G1 cell cycle arrest and cells treated with VAE a G2/M arrest. After application of the two drugs in combination both G0/G1 and G2/M arrest was observed. VEGF secretion of SK-BR-3 cells was significantly inhibited by sole treatment with Trastuzumab or VAE. Combined treatment of Trastuzumab and VAE at clinically relevant doses showed additive inhibitory effects on VEGF secretion.

Conclusions: VAE did not interfere with cytostatic effects of Trastuzumab on SK-BR-3 cells in vitro. Our in vitro results suggest that no risk of safety by herb drug interactions has to be expected from the exposition of cancer cells to Trastuzumab and VAE simultaneously. In contrast, VAE and Trastuzumab seem to exhibit complementary anti-cancer effects in vitro.
\end{abstract}

Keywords: Mistletoe (Viscum album L.), Iscador, Trastuzumab, Herceptin, Her-2, Drug interactions, Cytostasis, Apoptosis, Cell cycle, VEGF

\section{Background}

Breast cancer is the most common cancer in females worldwide with about $12 \%$ of all new cancer cases and $25 \%$ of all cancers in women $[1,2]$. In $15-25 \%$ of human breast cancers the HER2 receptor, encoded by the proto-oncogene ERBB2 is amplified. Her-2 overexpression has been correlated with poor clinical outcome. The selective, fully humanized recombinant monoclonal antibody (mAb) Trastuzumab (Herceptin) was developed

* Correspondence: u.weissenstein@hiscia.ch

${ }^{1}$ Iscador AG, Arlesheim, Switzerland

Full list of author information is available at the end of the article to target HER2 with high affinity. It acts as an inhibitor of signal transduction and has been shown to decrease the proliferation of human tumor cells that overexpress HER2 both in vitro and in vivo $[3,4]$. Besides primary and metastatic Her2 positive breast cancer, use of Trastuzumab is approved for the treatment of HER2-overexpressing metastatic gastric or gastroesophageal junction adenocarcinoma.

Breast cancer patients increasingly use CAM in addition to conventional therapy with the attempt to strengthen their immune system, prevent recurrence, to improve quality of life and feel more in control. With a prevalence of 40-80 \% CAM use is high [5-7]. In Europe 
especially the application of mistletoe preparations is widespread [8-10]. Extracts derived from mistletoe (Viscum album) have been shown to display anti-tumoral, anti-angiogenetic and immune-potentiating activities [11-14]. Mistletoe preparations are used either alone or in combination with chemo-, radio- and hormonal and probably with new molecular targeted therapies to treat cancer or to lessen the side effects of anticancer drugs. Clinical studies suggest the association of mistletoe treatment with a better survival, a reduction of side effects of traditional therapies and with an increase of quality of life [15-18].

In a former in vitro study we demonstrated that mistletoe extracts did not influence the cytostatic and cytotoxic activity of several common conventional chemotherapeutic drugs when applied in concentrations typical for clinical use [19].

The aim of the present study was to investigate possible effects of clinically relevant doses of a standardized Viscum album extract (VAE) on the in vitro efficacy of Trastuzumab with regard to proliferation, apoptosis, cell cycle kinetics and production of vascular endothelial growth factor (VEGF) using the Her-2 positive cell line SK-BR-3.

\section{Methods}

\section{Mistletoe extracts and drugs}

The aqueous, fermented mistletoe preparation Iscador $\mathrm{M}$ spec. $5 \mathrm{mg}$ (VAE, host tree Malus domestica, Lot 1109/ 2103/2, total mistletoe lectin concentration $287 \mathrm{ng} / \mathrm{ml}$ ) was obtained from Iscador AG (Arlesheim, Switzerland). Vials of Iscador $\mathrm{M}$ spec. $5 \mathrm{mg}$, stored at $4{ }^{\circ} \mathrm{C}$ were used as VAE stock solution.

Trastuzumab (Herceptin ${ }^{\circ}$ (Lot. B4009) was kindly provided by Roche Pharma AG Switzerland. Stock solution $\left(15 \mathrm{mg} / \mathrm{ml}\right.$ in deionized water) was stored at $-20{ }^{\circ} \mathrm{C}$.

\section{Cell culture}

Human breast carcinoma cell line SK-BR-3 was obtained from DSMZ (German Collection of Microorganisms and Cell Cultures, Braunschweig, Germany).

SK-BR-3 cells were cultured in McCoy's 5A Medium (Sigma-Aldrich) supplemented with $20 \%$ FBS, 2 mM LGlutamine and $1 \%$ Penicillin - Streptomycin in a humidified atmosphere with $5 \% \mathrm{CO}_{2}$ at $37{ }^{\circ} \mathrm{C}$. Cell line was maintained in exponential growth and cells from subconfluent monolayers were harvested by trypsinEDTA (Sigma-Aldrich) to carry out the experiments. For measurement of the parameters, the cell cultures were used within 6-8 weeks after thawing.

\section{Proliferation assay}

Proliferation was indirectly assessed using the cell proliferation reagent WST-1 (Roche, Mannheim, Germany).
Cells $\left(1.5 \times 10^{4}\right.$ in $\left.100 \mu \mathrm{l}\right)$ were plated in triplicates in 96-well plates. After $4-6$ h to allow attachment, the drugs were added in various concentrations (see below). Proliferation rate was measured after $4 \mathrm{~h}$ of incubation with the WST-1 reagent in triplicate. The upper limit of absorbance was $2.0-2.1$. Values are given in percent inhibition of proliferation relative to untreated control.

\section{Cell death analysis}

Apoptosis/necrosis was measured using the Annexin VFITC Apoptosis Detection Kit I (BD Biosciences Pharmingen $^{\text {nux }}$, San Diego, CA, USA). Briefly: $2 \times 10^{5}$ cells were incubated with Annexin V-FITC and 7-AAD at room temperature in the dark. Thereafter, the samples were analysed in a flow cytometer (FACS Calibur, BD Biosciences, San Jose, CA). Early apoptotic cells: Annexin V-FITC positive and 7-AAD negative. Late apoptotic/necrotic cells: Annexin V-FITC positive and 7-AAD positive. Values are given in percent of total cell number.

\section{Cell cycle analysis}

Cell cycle analysis was performed using the CycleTest ${ }^{\text {th }}$ Plus DNA reagent Kit (BD Biosciences, San Jose, CA) according to manufacturer's instructions. DNA QC particles were used for quality control. Data were analyzed using the FlowJo 7.6.1 software (Ashland, OR, USA).

\section{Drug concentrations in the assays}

Preceding the actual experiments the optimal concentration range and the optimal incubation time regarding treatment efficacy was determined for Trastuzumab using the WST-1 proliferation assay (data not shown). The concentration range for Trastuzumab was higher than the corresponding dose of $2-4 \mathrm{mg} / \mathrm{kg}$ used in clinic [20].

In the main experiments, Trastuzumab was added to culture medium at following concentrations: $0,0.1,1.0$, 10 and $100 \mu \mathrm{g} / \mathrm{ml}$. Depending on the assay, each dose of the drug was combined with $0,0.1,1.0,10$ or $100 \mu \mathrm{g} / \mathrm{ml}$ of VAE for measuring proliferation, apoptosis/necrosis, cell cycle and VEGF secretion. Typical clinical Iscador concentrations for subcutaneous application are 0.1 and $1 \mu \mathrm{g} / \mathrm{ml}$, roughly corresponding to an injection of $5 \mathrm{mg}$ Iscador when referring to the body weight and the amount of circulating blood, respectively. Concentrations of about $10 \mu \mathrm{g} / \mathrm{ml}$ correspond to doses used for intravenous Iscador applications. Parameters were measured after the appropriate incubation time.

\section{VEGF ELISA}

$2.5 \times 10^{5}$ SK-BR-3 cells were plated in 6-well plates. After 4-6 $\mathrm{h}$ to allow attachment, the drugs were added in various concentrations in a final volume of $2 \mathrm{ml}$ per 
well. Cell culture supernatants were collected after 3 days (3d) of incubation, centrifuged and stored in aliquots at $-80{ }^{\circ} \mathrm{C}$ until analysis. VEGF-A concentrations were determined using a commercial Human VEGF ELISA kit (Sigma-Aldrich, MO, USA) according to manufacturer's instructions. The detection limit was $10 \mathrm{pg} / \mathrm{ml}$.

\section{Data analysis}

Three independent experiments were carried out for each combination of Trastuzumab and mistletoe extract. Data were analyzed with full 3-way analysis of variance (ANOVA, Type 6 decomposition) using Statistica 6.0 (Statsoft Inc., Tulsa, USA). For pairwise comparisons, the protected Fisher LSD-test was used. This procedure gives a good safeguard against false-positive as well as false-negative results [21]. Limit of significance was defined as $p<0.05$.

\section{Results}

\section{Proliferation}

The growth kinetic analysis of SK-BR-3 cells revealed different effects of VAE and Trastuzumab when used as single agents. A dose dependent anti-proliferative effect of VAE was observed at concentrations $\geq 10 \mu \mathrm{g} / \mathrm{ml}$ after $3 \mathrm{~d}$ of incubation. After $7 \mathrm{~d}$ a significant growth inhibition of $60 \%$ with the clinically relevant concentration $1 \mu \mathrm{g} /$ $\mathrm{ml}$ was detected and no proliferating cells were left at VAE concentrations of 10 and $100 \mu \mathrm{g} / \mathrm{ml} .0 .1 \mu \mathrm{g} / \mathrm{ml}$ VAE did not significantly affect the proliferation of tumor cells (Fig. 1a).

Figure $1 \mathrm{~b}$ presents mean proliferation values of the breast carcinoma cell line SK-BR-3 treated with different concentrations of Trastuzumab. The maximal cytostatic effect attained by the treatment with Trastuzumab alone was $63 \%$ after $7 \mathrm{~d}$ of incubation. With $1 \mu \mathrm{g} / \mathrm{ml}$ Trastuzumab a plateau of inhibition was reached resulting in no further enhancement at concentrations of 10 and $100 \mu \mathrm{g} / \mathrm{ml}$.

After simultaneous application of VAE and Trastuzumab, concentrations of $1-100 \mu \mathrm{g} / \mathrm{ml}$ VAE significantly enforced the antiproliferative effect of all Trastuzumab concentrations applied $(p<0.01)$, whereas $0.1 \mu \mathrm{g} / \mathrm{ml}$ did not show any modulation (Fig. 1c, d).
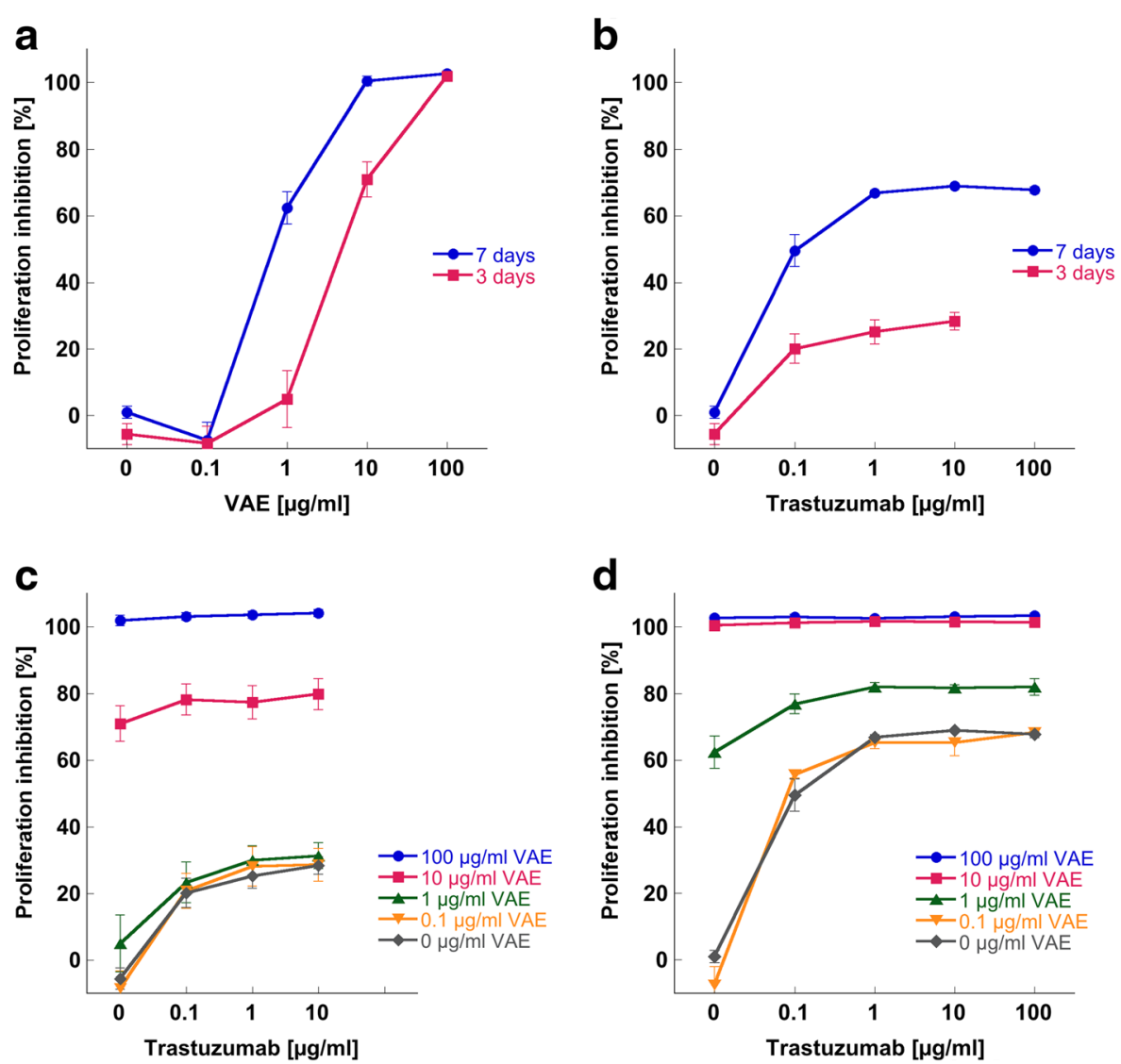

Fig. 1 Dose response effect of VAE, Trastuzumab and their combinations on the proliferation of SK-BR-3 cells. Proliferation inhibition by (a) VAE treatment after $3 d$ and $7 d$, (b) Trastuzumab treatment after $3 d$ and $7 d$ and combined VAE and Trastuzumab treatment after (c) $3 d$ and (d) $7 d$, are shown. Cell growth kinetic was assessed with the WST-1 assay. Results are presented as mean \pm SE from three independent experiments 


\section{Apoptosis}

To characterize the type of cell death induced by VAE and Trastuzumab, respectively, Annexin V/7-AAD dual staining was used to evaluate the apoptotic cells. VAE concentrations between 0.1 and $1 \mu \mathrm{g} / \mathrm{ml}$ had no significant effect on the viability of SK-BR-3 cells; VAE at $10 \mu \mathrm{g} / \mathrm{ml}$ induced apoptosis $(p<0.001$, F-test, Fig. 2).

With $10 \mu \mathrm{g} / \mathrm{ml}$ VAE after $3 \mathrm{~d}$ the proportion of early apoptotic cells was elevated from $7.1 \%$ in the untreated control to $32.8 \%$ and that of late apoptotic/ necrotic cells from $7.0 \%$ in control to $12.1 \%$ (Fig. 3a, b). After $7 \mathrm{~d}$ the proportion of early apoptotic cells raised from $9.0 \%$ in the control to $17.4 \%$ and that of late apoptotic/necrotic cells from $18.7 \%$ in control to $78.7 \%$, respectively (Fig. 3c, d).

In our experimental setup Trastuzumab alone did not exert a dose dependent pro-apoptotic or cytotoxic effect. After $3 \mathrm{~d}$ and after $7 \mathrm{~d}$ treatment of SK-BR-3 cells with concentrations of Trastuzumab between 0.1 and $100 \mu \mathrm{g} /$ $\mathrm{ml}$, the proportions of apoptotic or dead cells remained unaltered compared to the untreated control $(p>0.05$, F-test) and Trastuzumab did not significantly alter VAE induced apoptosis $(p>0.8$, F-test for interaction, Fig. 3), though there was a tendency that Trastuzumab enforced the pro-apoptotic effect of $10 \mu \mathrm{g} / \mathrm{ml} \mathrm{VAE}$ after 3 days (Fig. 3a).

\section{Cell cycle analysis}

VAE at $10 \mu \mathrm{g} / \mathrm{ml}$ influenced cell cycle kinetics by inducing a significant $\mathrm{G} 2 / \mathrm{M}$ accumulation of 11 vs. $7 \%$ in control $(P<0.001$, Fig. 4a). The proportion of $S$ phase cells declined from 31 to $24 \%$. Lower VAE concentrations had no effect. VAE did not induce a G0/G1 accumulation at any concentration $(p>0.28$, F-test).

As shown in Fig. 4b, Trastuzumab induced a dose dependent significant accumulation of SK-BR-3 cells in G0/G1 cell cycle phase $(p<0.001$, F-test). The maximal percentage of cells found in G0/G1 phase was $71 \%$ after treatment with $100 \mu \mathrm{g} / \mathrm{ml}$ Trastuzumab, compared to $60 \%$ in the control. Trastuzumab did not induce a $\mathrm{G} 2 / \mathrm{M}$ accumulation $(p>0.12$, Ftest).

Simultaneous treatment of cells with $10 \mu \mathrm{g} / \mathrm{ml}$ VAE and Trastuzumab induced a block in both cell cycle phases, G0/G1 (67 \% with $1 \mu \mathrm{g} / \mathrm{ml}$ Trastuzumab and $66 \%$ with $10 \mu \mathrm{g} / \mathrm{ml}$ Trastuzumab) and G2/M (10 \% with $1 \mu \mathrm{g} / \mathrm{ml}$ Trastuzumab and $13 \%$ with $10 \mu \mathrm{g} / \mathrm{ml}$ Trastuzumab) (Fig. 4c, d). VAE concentrations of 0.1 and $1 \mu \mathrm{g} / \mathrm{ml}$ did not influence the effect of Trastuzumab on cell cycle. There was no statistically significant interaction in the ANOVA model, which means that the effects of Trastuzumab and VAE were additive.

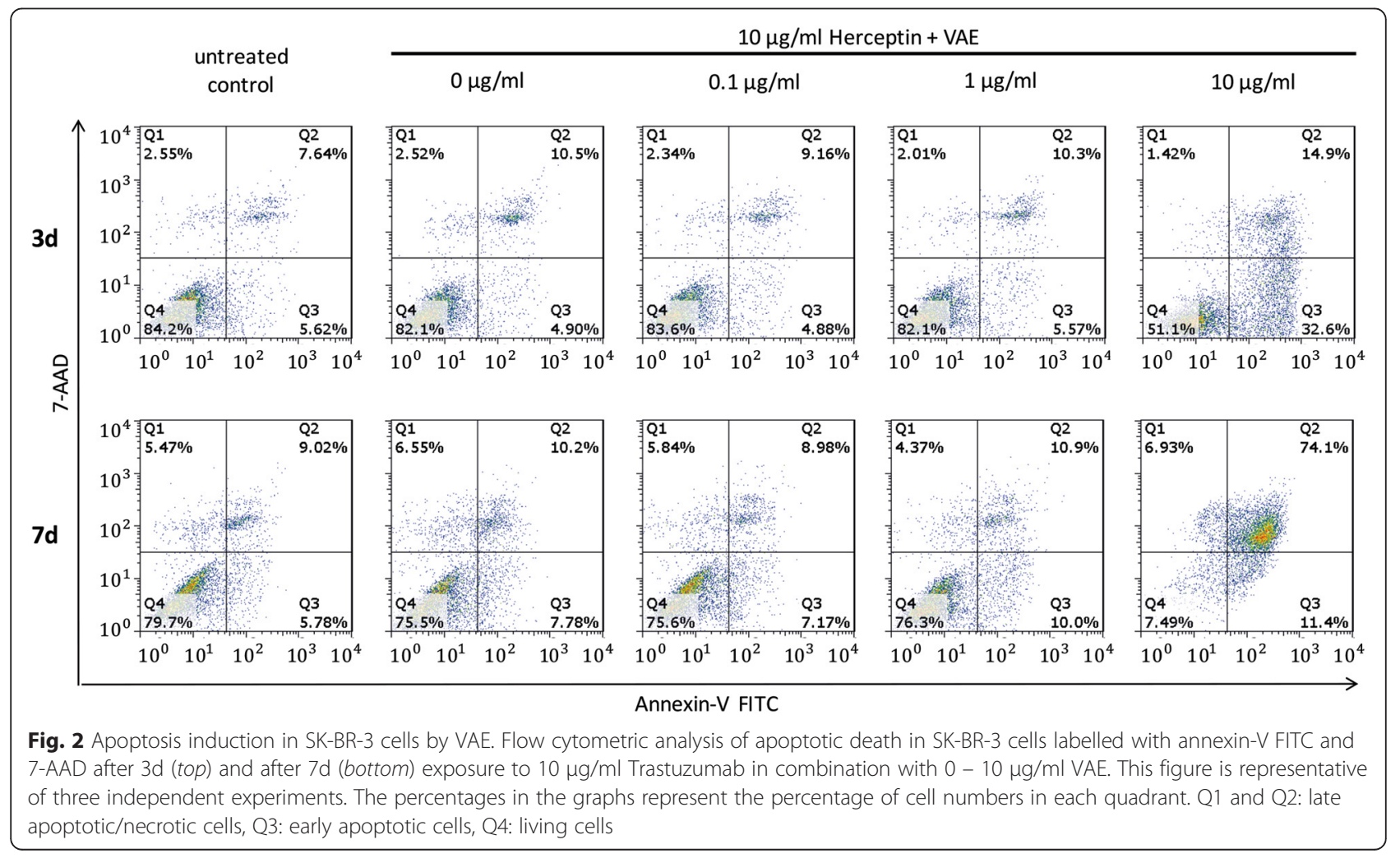



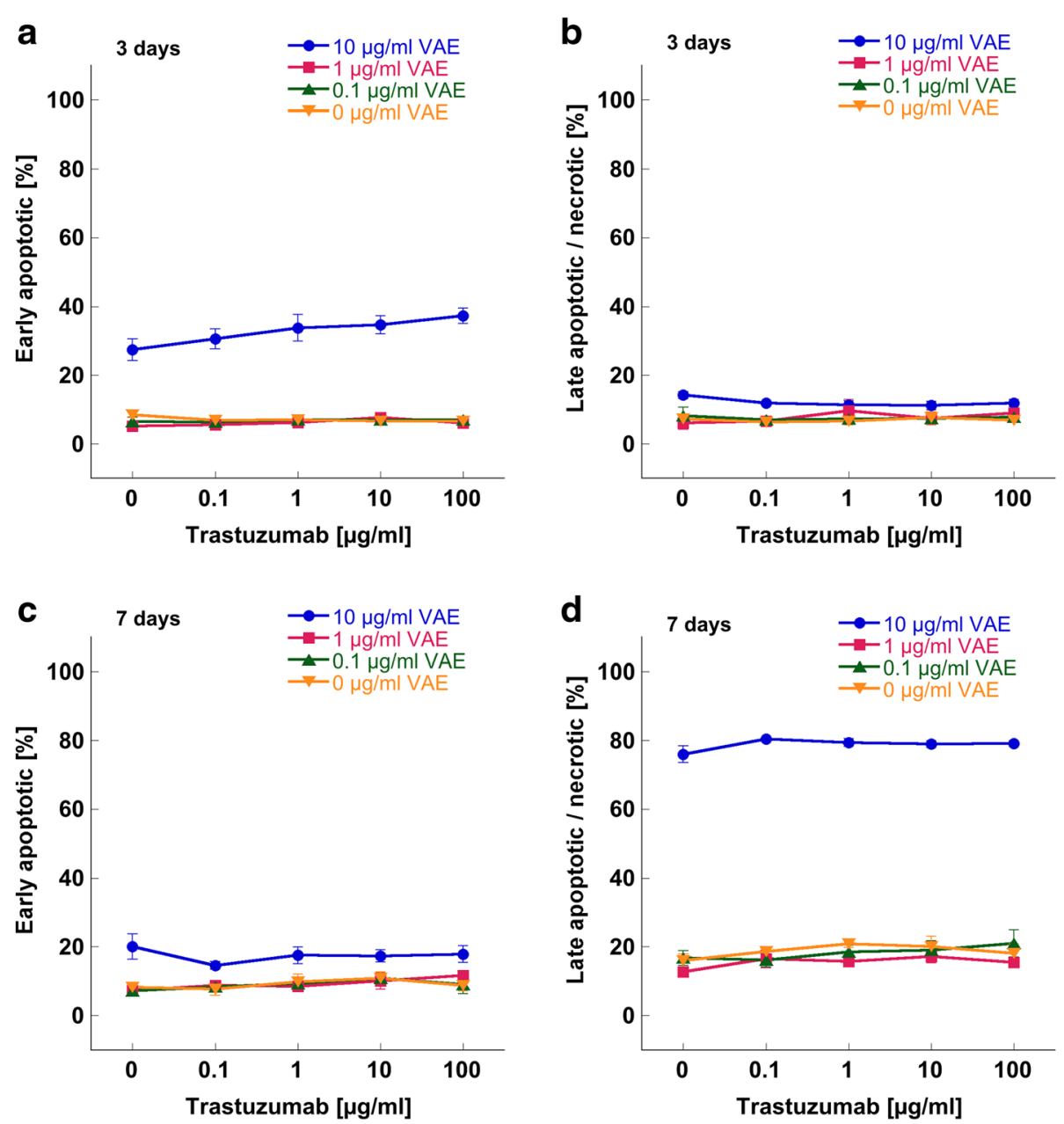

Fig. 3 Apoptosis induction in SK-BR-3 cells. Mean values ( \pm SE) of (a) early apoptosis and (b) late apoptosis/necrosis after $3 \mathrm{~d}$ and of (c) early apoptosis and (d) late apoptosis/necrosis after $7 \mathrm{~d}$ treatment with different concentrations of Trastuzumab combined with different concentrations of VAE are presented

\section{VEGF production}

We assessed whether treatment with VAE and/or Trastuzumab were able to reduce VEGF production in SK-BR-3 cells. Untreated SK-BR-3 cells were found to secrete appreciable quantities of VEGF (approximately $1500 \mathrm{pg} / \mathrm{ml} / 2.5 \times 10^{5}$ seeded cells) into the media. Both VAE and Trastuzumab reduced VEGF production $(p<0.001$, F-test $)$ without a significant interaction in the ANOVA model $(p=0.22)$, meaning that the effects on VEGF were independent (additive). As shown in Fig. 5, $1 \mu \mathrm{g} / \mathrm{ml}$ VAE reduced VEGF production to $71 \%(p<0.01)$, whilst Trastuzumab induced a decrease in VEGF production, which reached about $61 \%$ at the concentrations of 1 and $10 \mu \mathrm{g} / \mathrm{ml}$ antibody and $48 \%$ at the concentration of $100 \mu \mathrm{g} / \mathrm{ml}$ $(p<0.001$ for all concentrations). Co-treatment with $1 \mu \mathrm{g} / \mathrm{ml}$ VAE and Trastuzumab revealed the most pronounced effects.
Proliferation inhibition is a possible underlying cause for lower VEGF concentrations in culture supernatants of treated cells. We investigated this hypothesis by calculating VEGF production relative to proliferation (Fig. 1) for the relevant concentrations of VAE and Trastuzumab. In this evaluation, application of $1 \mu \mathrm{g} / \mathrm{ml} \mathrm{VAE}$ led to a significant reduction of VEGF production (86\%, $p<0.05$ ); Trastuzumab did not yield any significant effects at any concentration applied $(p>0.15)$.

\section{Discussion}

In our in vitro study we investigated the interaction between Trastuzumab, a monoclonal antibody used for the treatment of Her-2 positive breast cancer and an aqueous fermented mistletoe extract, frequently used by cancer patients as supportive therapy. No inhibition of antitumor efficacy of Trastuzumab by VAE was detected in any of our experimental setups. The same applies to 

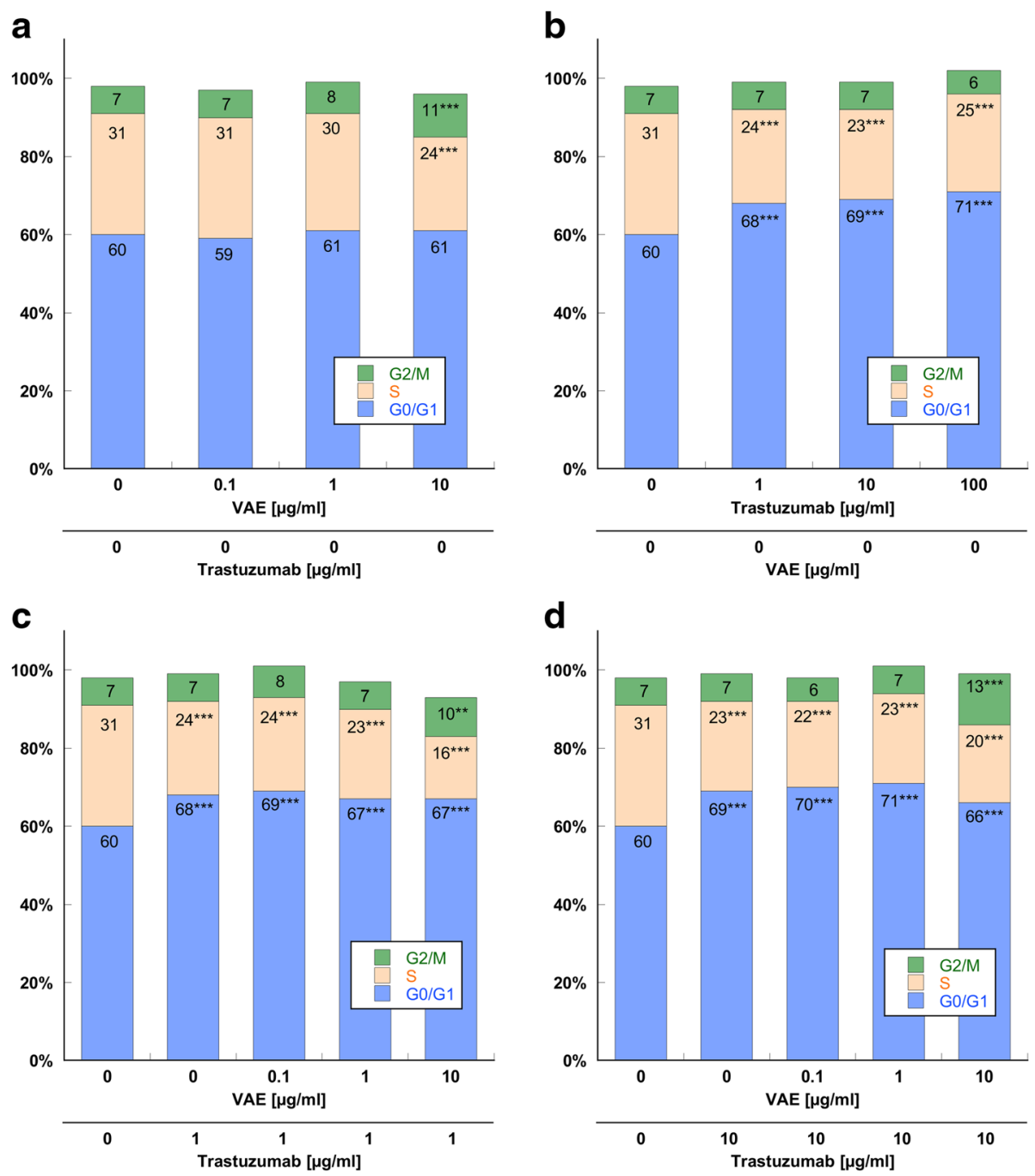

Fig. 4 SK-BR-3 cell cycle analysis of cells treated with (a) VAE (b) Trastuzumab (c) $1 \mu \mathrm{g} / \mathrm{ml}$ Trastuzumab and VAE and (d) $10 \mu \mathrm{g} / \mathrm{ml}$ Trastuzumab and VAE. Cells were harvested after 3d, fixed, stained and analyzed for DNA content by flow cytometry. The distribution and percentage of cells in G0/G1, S and G2/M phase of the cell cycle are indicated. Results are presented as mean values from three independent experiments. (SE values are omitted for clarity). Significance values are given relative to the VAE and Trastuzumab untreated controls $\left({ }^{* *} p<0.01,{ }^{* *} p<0.001\right)$.

Discrepancies from $100 \%$ can be attributed to slight gating differences and the display of mean values

the antitumor efficacy of VAE, which was not inhibited by Trastuzumab. When used individually, VAE and Trastuzumab showed dissimilar anti-proliferative effects. The growth inhibitory effect of Trastuzumab was associated with G0/G1 accumulation but not with apoptosis. VAE alone and in combination with Trastuzumab revealed a distinct pro-apoptotic activity and a G2/M arrest. Both Trastuzumab and VAE significantly inhibited VEGF production, alone as well as in combination.

Little is known so far about possible drug interactions of mistletoe preparations with Trastuzumab. In a retrospective case series study examining the tolerability of the simultaneous treatment with mistletoe preparations and Herceptin in nine breast cancer patients no new side effects that could be attributed to the well tolerated combined treatment were observed. However an increased incidence of mild reactions consisting of wellknown side effects of either mistletoe or Herceptin treatment was noted and therefore a special attention was recommended (A.P. Simões-Wuest, personal communication). A prospective study would provide more conclusive information.

The aim of our study was to investigate if clinically relevant doses of VAE interfere with Trastuzumab in vitro by influencing its anti-tumoral efficacy on proliferation, cytotoxicity, cell cycle progression and VEGF production of a Her2 positive breast cancer cell line. Trastuzumab and VAE as well as their combinations 


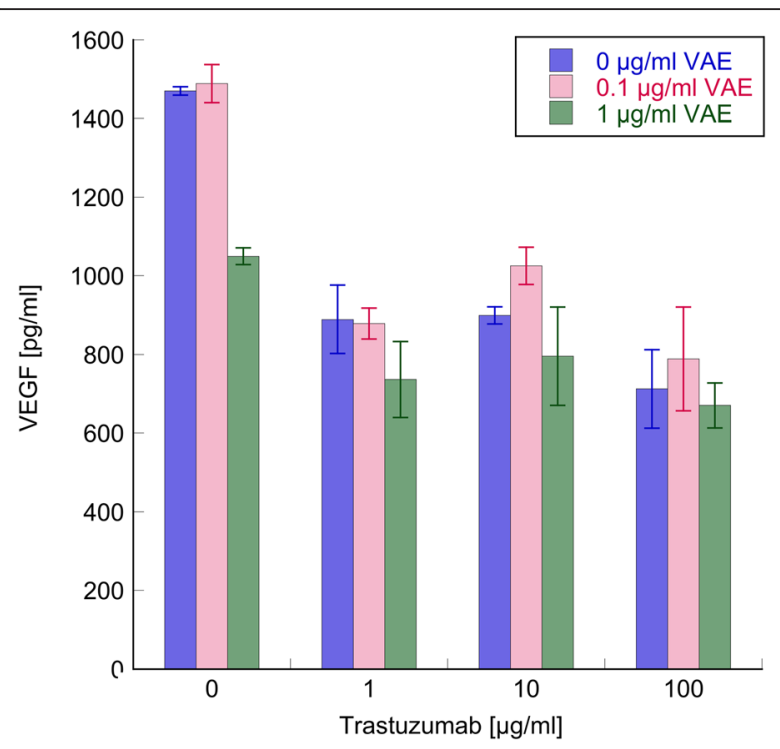

Fig. 5 Inhibitory effect of Trastuzumab, VAE and their combinations on VEGF production of SK-BR-3 human breast carcinoma cells in vitro. VEGF was measured by ELISA in cell culture supernatants after $3 d$ of treatment. Results are presented as mean \pm SE from three independent experiments

induced dose and time dependent anti-proliferative effects on SK-BR-3 cells. Our results regarding growth inhibition and lack of apoptosis induction by Trastuzumab alone are comparable to data shown previously [22-25]. Depending on the treatment time VAE doses $\geq 1 \mu \mathrm{g} / \mathrm{ml}$ induced a $60 \%$ and $\geq 10 \mu \mathrm{g} / \mathrm{ml}$ a total inhibition of cell proliferation. Concomitant treatment already with the clinically relevant dose of $1 \mu \mathrm{g} / \mathrm{ml}$ VAE could lead to an augmentation of Trastuzumab induced cytostasis for about $13-15 \%$.

Much of the Trastuzumab induced growth-inhibitory effects might be due to a transient cell cycle arrest. Consistent with former studies we observed a distinct G0/G1 accumulation in Trastuzumab treated SK-BR-3 cells [26, 27]. As an initial effect of specific antibodies on Her-2 receptor signaling, a redirection of cyclin-dependent kinase (Cdk) inhibitor p27 (also known as KIP1) onto $\mathrm{Cdk} 2$ complexes was proposed, resulting in the inhibition of G1/S progression. The p27-Cdk2 complex accumulation was correlated with reduced protein levels of D-type cyclins and transcription factor c-Myc [28].

Growth inhibition by higher VAE concentrations detected in our study could be strongly related to proapoptotic activity. Induction of apoptosis is a welldefined mechanism exerted by mistletoe lectins (ML). One of the constituents of VAE is ML-I, a heterodimeric ribosome-inactivating protein II (RIP II) composed of an A-chain with the capacity to depurinate a critical adenosine in the $28 \mathrm{~S}$ ribosomal RNA and a sialic acid-specific
B chain that binds to cell surfaces and facilitates internalization of the A-chain [29]. ML, like other type II RIPs induce cell apoptosis in vitro and in vivo probably via an intracellular pathways described as "ribotoxic stress response" that directly targets mitochondria and leads to apoptosis through a stress-mediated signalling pathway [30-32]. The ML-I induced apoptosis is reported to be receptor-independent. Cytochrome $\mathrm{c}$ is rapidly released from mitochondria into the cytosol accompanied by proteolytic activation of caspase- $8,-9,-3$ and -2 and decreased expression of anti-apoptotic molecules [33, 34]. If the ribosome inhibiting activity of $\mathrm{ML}$ or another mechanism or constituent is responsible for the proliferation inhibiting effect of $1 \mu \mathrm{g} / \mathrm{ml} \mathrm{VAE}$, a concentration were no apoptosis induction was observed, has to be evaluated.

VAE at $10 \mu \mathrm{g} / \mathrm{ml}$ induced a G2/M arrest and simultaneous treatment with Trastuzumab and $10 \mu \mathrm{g} / \mathrm{ml}$ VAE induced the accumulation of SK-BR-3 cells in both G0/G1 and $\mathrm{G} 2 / \mathrm{M}$ cell cycle phases. The $\mathrm{G} 2 / \mathrm{M}$ phase arrest with a decline in the proportion of S-phase cells after treatment with VAE was observed in parallel to the rise of apoptotic cell content. It is known, that the processes of cell cycle progression and programmed cell death use and control shared factors like p53, p21, RB, c-Myc and several cyclin-dependent kinases (Cdks) and their regulators [35]. Activated p53 can cause apoptosis, G0/G1 arrest but also functions at the $\mathrm{G} 2 / \mathrm{M}$ checkpoint [36] but in breast cancer SK-BR-3 cell line the p53 gene is mutated [37]. The investigation of recombinant ML effects on tumor cell proliferation in p53-wild-type and -deficient murine embryo fibroblasts indicated a predominantly p53-independent mechanism of apoptosis induction by rML [38]. Changes in cell cycle may be as well a p53-independent secondary effects of ribosome inhibition and ribotoxic stress by VAE that block entry into mitosis. G2/M arrest and apoptosis can result from upregulation of p53, p21, Chk1 and Chk2 (checkpoint kinases 1 and 2) and downregulation of cyclin B1 or cyclin D1 [35, 39, 40]. Miyoshi et al. demonstrated a marked elevation of p21 mRNA and protein upon exposure of a human myeloid cell line to ML (VAA, Viscum album agglutinin) [41]. P21 participates in the maintenance of cells in G1-phase arrest but also in G2/ $M$ through multiple mechanisms [42, 43]. In squamous cell carcinoma cell lines VAE treatment led to a substantial decrease in the expression level of Cyclin D1 [44]. Cyclin D1 performs a critical cell cycle regulatory function during G2 phase [45] and silencing of Cyclin D1 also had an effect on apoptosis induction in several squamous cell carcinoma cell lines [46].

In summary our results suggest that Trastuzumab and VAE influenced different cell cycle regulators in SK-BR3 cells whereby the G2/M arrest induced by VAE 
seemed to be correlated to apoptosis related events. Molecular investigations could provide further confirmation on this subject.

One of the fundamental physiological processes of tumor growth is angiogenesis, mediated by pro- and anti-angiongenic factors [47, 48]. Her-2 signaling affects the expression of angiogenic factors like VEGF, Interleukin-8 and thrombospondin-1 [49]. VEGF stimulates endothelial cell proliferation and migration and causes the degradation of the basement membrane in microvessel walls. In cancer cells VEGF is supposed to promote proliferation, survival and invasiveness $[50,51]$. In our experiments we demonstrated a significant inhibition of VEGF production by SK-BR-3 cells treated with Trastuzumab. Concomitant treatment with VAE at clinically relevant doses did not negatively affect the inhibitory efficacy of Trastuzumab, co-treatment with $1 \mu \mathrm{g} / \mathrm{ml}$ VAE revealed even lower VEGF values. In SK-BR-3 cell cultures treated with Trastuzumab the inhibition of VEGF correlated with growth reduction and seemed not to be a primary effect. Several in vivo and in vitro studies demonstrated that the treatment with Her-2 neutralizing antibodies like Trastuzumab induced a down-regulation of VEGF mRNA and protein levels in Her-2-overexpressing tumors resected from xenografted mice as well as in Her2 overexpressing breast tumor cell lines, associated with inhibition of tumor growth and vessel formation $[49,52]$.

Sole VAE caused a significant VEGF diminution that was mainly independent of proliferation inhibition what indicates a direct suppressive effect of VAE on VEGF expression besides the reduction of VEGF protein content in cell culture media due to lower cell densities. If this effect is specific or a consequence of ribosome inhibiting events has to be proven. Varying results on the effect of mistletoe on angiogenesis exist. Inhibitory impact of VAE on vessel development in vitro and in vivo was associated with apoptosis induction [53] but in another study VAE-treated glioblastoma cells down-regulated central genes involved in glioblastoma progression and malignancy, among others VEGFA, without parallel cytotoxicity and apoptosis [54].

In our in vitro study we intended to contribute information about possible interactions of VAE with Trastuzumab. We addressed some of the mechanisms of action proposed for Trastuzumab [55] using a Her2 positive breast cancer cell line. One of the limitations of working with cell lines is, that interaction and protection mechanisms otherwise available from the donor organism are eliminated. Although we could not detect pro-apoptotic activity of Trastuzumab in our experiments it has been shown that neoadjuvant treatment with Trastuzumab in vivo induced some apoptosis in primary breast cancers [56]. In addition to the direct effects on cancer cells, there was evidence that antibody-dependent cellular cytotoxicity (ADCC) plays an important role in the antitumor activity of Trastuzumab, a mechanism we could not explore in our in vitro experiments. In vivo, specific immune cells could recognize and lyse tumor cells coated with the antibody. As mistletoe was reported to exert immune-modulating activities that may enhance the host defense system against tumors it would be interesting to investigate if ADCC could be fostered by mistletoe co-treatment.

\section{Conclusions}

Aqueous, fermented mistletoe extract did not attenuate the anti-tumor activity of Trastuzumab in vitro when applied in concentrations typical for clinical use. We investigated the effects of VAE concomitant to Trastuzumab on proliferation, apoptosis induction, cell cycle progression and VEGF expression in a Her-2 overexpressing breast cancer cell line and could show concentration dependent additive effects. Our in vitro results suggest that VAE can be used without impairment of Trastuzumab efficacy. Further studies should be performed to complete the knowledge about drug interactions and patient safety and to investigate if the positive additive effects by VAE treatment concomitant to Trastuzumab could also be found in vivo.

\begin{abstract}
Abbreviations
ADCC antibody-dependent cellular cytotoxicity; CAM complementary and alternative medicine; Cdk cyclin-dependent kinase; EDTA Ethylenediaminetetraacetic acid; FBS Fetal bovine serum; ML mistletoe lectin; RIP || ribosome-inactivating protein II; rML recombinant mistletoe lectin; VAE Viscum album extract; VEGF vascular endothelial growth factor; WST-1 water soluble tetrazolium-1
\end{abstract}

\section{Acknowledgements}

The authors thank Roche Pharma AG Switzerland to provide Herceptin for the purpose of a preclinical research project and Christoph Jaeggy for preparing the figures for publication.

\section{Funding}

The study was funded by Iscador AG, the author's employer and the manufacturer of VAE used for the study.

\section{Availability of data and materials}

The datasets supporting the conclusions of this article are included within the article.

\section{Authors' contributions}

UW and MK made substantial contributions to the conception and design of the study, MK, UW and UR performed analyses, SB performed statistical analysis, UW drafted, and KU and SB critically revised the manuscript. All authors read and approved the final manuscript.

\section{Competing interests}

We declare following interests: The study was funded by Iscador AG, the author's employer and the manufacturer of VAE used for the study, which however had no influence on the analysis or interpretation of data, on the writing of manuscripts or on the decision to submit the manuscripts for publication.

Consent for publication

Not applicable. 


\section{Ethics approval and consent to participate}

Not applicable.

\author{
Author details \\ 'Iscador AG, Arlesheim, Switzerland. 'Institute of Integrative Medicine, \\ Witten/Herdecke University, Herdecke, Germany.
}

Received: 17 March 2016 Accepted: 23 July 2016

Published online: 04 August 2016

\section{References}

1. Ferlay J, Soerjomataram I, Ervik M, Dikshit R, Eser S, Mathers C, Rebelo M, Parkin DM, Forman D, Bray F. GLOBOCAN 2012 v1.1, Cancer Incidence and Mortality Worldwide: IARC CancerBase No. 11 [Internet]. Lyon: Internationa Agency for Research on Cancer; 2014. Available from: http://globocan.iarc.fr, accessed on 20/06/2016

2. Ferlay J, Steliarova-Foucher E, Lortet-Tieulent J, Rosso S, Coebergh JW, Comber $H$, Forman D, Bray F. Cancer incidence and mortality patterns in Europe: estimates for 40 countries in 2012. Eur J Cancer. 2013;49(6):1374-403.

3. Drebin JA, Link VC, Greene MI. Monoclonal antibodies specific for the neu oncogene product directly mediate anti-tumor effects in vivo. Oncogene. 1988;2(4):387-94.

4. Sliwkowski MX, Lofgren JA, Lewis GD, Hotaling TE, Fendly BM, Fox JA. Nonclinical studies addressing the mechanism of action of trastuzumab (Herceptin). Semin Oncol. 1999;26(4 Suppl 12):60-70.

5. Buettner $\mathrm{C}$, Kroenke $\mathrm{CH}$, Phillips RS, Davis RB, Eisenberg DM, Holmes MD Correlates of use of different types of complementary and alternative medicine by breast cancer survivors in the nurses' health study. Breast Cancer Res Treat. 2006;100(2):219-27.

6. Henderson JW, Donatelle RJ. Complementary and alternative medicine use by women after completion of allopathic treatment for breast cancer. Altern Ther Health Med. 2004;10(1):52-7.

7. Nagel G, Hoyer H, Katenkamp D. Use of complementary and alternative medicine by patients with breast cancer: observations from a health-care survey. Support Care Cancer. 2004;12(11):789-96.

8. Templeton AJ, Thurlimann B, Baumann M, Mark M, Stoll S, Schwizer M, Dietrich D, Ruhstaller T. Cross-sectional study of self-reported physical activity, eating habits and use of complementary medicine in breast cancer survivors. BMC Cancer. 2013:13:153.

9. Fasching PA, Thiel F, Nicolaisen-Murmann K, Rauh C, Engel J, Lux MP, Beckmann MW, Bani MR. Association of complementary methods with quality of life and life satisfaction in patients with gynecologic and breast malignancies. Support Care Cancer. 2007;15(11):1277-84

10. Molassiotis A, Fernadez-Ortega P, Pud D, Ozden G, Scott JA, Panteli V, Margulies A, Browall M, Magri M, Selvekerova S, et al. Use of complementary and alternative medicine in cancer patients: a European survey. Ann Oncol. 2005;16(4):655-63

11. Harmsma M, Ummelen M, Dignef W, Tusenius KJ, Ramaekers FC. Effects of mistletoe (Viscum album L.) extracts Iscador on cell cycle and survival of tumor cells. Arzneimittelforschung. 2006;56(6A):474-82

12. Seifert $G$, Jesse $P$, Laengler A, Reindl T, Luth M, Lobitz S, Henze G, Prokop A, Lode HN. Molecular mechanisms of mistletoe plant extract-induced apoptosis in acute lymphoblastic leukemia in vivo and in vitro. Cancer Lett. 2008;264(2):218-28.

13. Park WB, Lyu SY, Kim JH, Choi SH, Chung HK, Ahn SH, Hong SY, Yoon TJ, Choi MJ. Inhibition of tumor growth and metastasis by Korean mistletoe lectin is associated with apoptosis and antiangiogenesis. Cancer Biother Radiopharm. 2001;16(5):439-47.

14. Elluru SR, van Huyen J-P D, Wootla B, Delignat S, Prost F, Negi V-S, Kaveri SV. Tumor regressive effects of Viscum album preparations - exploration of immunomodulatory mechanisms. Medicina. 2007;67(Supl. II):85-9.

15. Ostermann T, Raak C, Bussing A. Survival of cancer patients treated with mistletoe extract (Iscador): a systematic literature review. BMC Cancer. 2009; 9:451

16. Bussing A, Raak C, Ostermann T. Quality of life and related dimensions in cancer patients treated with mistletoe extract (iscador): a meta-analysis. Evid Based Complement Alternat Med. 2012:2012:219402.

17. Friedel WE, Matthes H, Bock PR, Zanker KS. Systematic evaluation of the clinical effects of supportive mistletoe treatment within chemo- and/or radiotherapy protocols and long-term mistletoe application in nonmetastatic colorectal carcinoma: multicenter, controlled, observational cohort study. J Soc Integr Oncol. 2009;7(4):137-45.

18. Troger W, Galun D, Reif M, Schumann A, Stankovic N, Milicevic M. Viscum album [L.] extract therapy in patients with locally advanced or metastatic pancreatic cancer: a randomised clinical trial on overall survival. Eur J Cancer. 2013:49(18):3788-97.

19. Weissenstein $U$, Kunz M, Urech K, Baumgartner S. Interaction of standardized mistletoe (Viscum album) extracts with chemotherapeutic drugs regarding cytostatic and cytotoxic effects in vitro. BMC Complement Altern Med. 2014;14:6

20. Slamon DJ, Leyland-Jones B, Shak S, Fuchs H, Paton V, Bajamonde A, Fleming T, Eiermann W, Wolter J, Pegram M, et al. Use of chemotherapy plus a monoclonal antibody against HER2 for metastatic breast cancer that overexpresses HER2. N Engl J Med. 2001;344(11):783-92.

21. Carmer SG, Swanson MR. An Evaluation of Ten Pairwise Multiple Comparison Procedures by Monte Carlo Methods. J Am Stat Assoc. 1973;68:66-74.

22. Emlet DR, Brown KA, Kociban DL, Pollice AA, Smith CA, Ong BB, Shackney SE. Response to trastuzumab, erlotinib, and bevacizumab, alone and in combination, is correlated with the level of human epidermal growth factor receptor-2 expression in human breast cancer cell lines. Mol Cancer Ther. 2007:6(10):2664-74.

23. Merlin $\mathrm{L}$, Barberi-Heyob M, Bachmann N. In vitro comparative evaluation of trastuzumab (Herceptin) combined with paclitaxel (Taxol) or docetaxel (Taxotere) in HER2-expressing human breast cancer cell lines. Ann Oncol. 2002;13(11):1743-8.

24. Brockhoff G, Heckel B, Schmidt-Bruecken E, Plander M, Hofstaedter F, Vollmann A, Diermeier S. Differential impact of Cetuximab, Pertuzumab and Trastuzumab on BT474 and SK-BR-3 breast cancer cell proliferation. Cell Prolif. 2007;40(4):488-507.

25. Tseng PH, Wang YC, Weng SC, Weng JR, Chen CS, Brueggemeier RW, Shapiro CL, Chen CY, Dunn SE, Pollak M, et al. Overcoming trastuzumab resistance in HER2-overexpressing breast cancer cells by using a nove celecoxib-derived phosphoinositide-dependent kinase-1 inhibitor. Mol Pharmacol. 2006:70(5):1534-41.

26. Hurrell T, Outhoff $K$. The in vitro influences of epidermal growth factor and heregulin-beta1 on the efficacy of trastuzumab used in Her-2 positive breast adenocarcinoma. Cancer Cell Int. 2013;13(1):97.

27. Pegram M, Hsu S, Lewis G, Pietras R, Beryt M, Sliwkowski M, Coombs D, Baly D, Kabbinavar F, Slamon D. Inhibitory effects of combinations of HER-2/neu antibody and chemotherapeutic agents used for treatment of human breast cancers. Oncogene. 1999;18(13):2241-51.

28. Lane HA, Beuvink I, Motoyama AB, Daly JM, Neve RM, Hynes NE. ErbB2 potentiates breast tumor proliferation through modulation of p27(Kip1)Cdk2 complex formation: receptor overexpression does not determine growth dependency. Mol Cell Biol. 2000;20(9):3210-23.

29. Muthing J, Meisen I, Bulau P, Langer M, Witthohn K, Lentzen H, Neumann U, Peter-Katalinic J. Mistletoe lectin I is a sialic acid-specific lectin with strict preference to gangliosides and glycoproteins with terminal Neu5Ac alpha 2-6Gal beta 1-4GICNAc residues. Biochemistry. 2004:43(11):2996-3007.

30. Hoessli DC, Ahmad I. Mistletoe Lectins: Carbohydrate-Specific Apoptosis Inducers and Immunomodulators. Curr Organic Chem. 2008:12(11):918-25.

31. Narayanan S, Surendranath K, Bora N, Surolia A, Karande AA. Ribosome inactivating proteins and apoptosis. FEBS Lett. 2005:579(6):1324-31.

32. Iordanov MS, Pribnow D, Magun $J$, Dinh TH, Pearson JA, Chen SL, Magun BE. Ribotoxic stress response: activation of the stress-activated protein kinase JNK1 by inhibitors of the peptidyl transferase reaction and by sequence-specific RNA damage to the alpha-sarcin/ricin loop in the $28 \mathrm{~S}$ rRNA. Mol Cell Biol. 1997;17(6):3373-81.

33. Bantel $H$, Engels $H$, Voelter W, Schulze-Osthoff $K$, Wesselborg S. Mistletoe lectin activates caspase-8/FLICE independently of death receptor signaling and enhances anticancer drug-induced apoptosis. Cancer Res. 1999;59(9): 2083-90.

34. Khil LY, Kim W, Lyu S, Park WB, Yoon JW, Jun HS. Mechanisms involved in Korean mistletoe lectin-induced apoptosis of cancer cells. World J Gastroenterol. 2007;13(20):2811-8.

35. Pucci B, Kasten M, Giordano A. Cell cycle and apoptosis. Neoplasia. 2000; 2(4):291-9.

36. Agarwal ML, Taylor WR, Chernov MV, Chernova OB, Stark GR. The p53 network. J Biol Chem. 1998;273(1):1-4.

37. Lacroix M, Toillon RA, Leclercq G. p53 and breast cancer, an update. Endocr Relat Cancer. 2006;13(2):293-325. 
38. Hostanska K, Vuong V, Rocha S, Soengas MS, Glanzmann C, Saller R, Bodis S, Pruschy M. Recombinant mistletoe lectin induces p53-independent apoptosis in tumour cells and cooperates with ionising radiation. $\mathrm{Br} J$ Cancer. 2003;88(11):1785-92.

39. Taylor WR, Stark GR. Regulation of the G2/M transition by p53. Oncogene. 2001;20(15):1803-15.

40. Bartek J, Lukas J. Chk1 and Chk2 kinases in checkpoint control and cancer. Cancer Cell. 2003;3(5):421-9.

41. Miyoshi N, Koyama Y, Katsuno Y, Hayakawa S, Mita T, Ohta T, Kaji K, Isemura M. Apoptosis induction associated with cell cycle dysregulation by rice bran agglutinin. J Biochem. 2001;130(6):799-805.

42. Choi YK, Seo HS, Choi HS, Choi HS, Kim SR, Shin YC, Ko SG. Induction of Fas-mediated extrinsic apoptosis, p21WAF1-related G2/M cell cycle arrest and ROS generation by costunolide in estrogen receptor-negative breast cancer cells, MDA-MB-231. Mol Cell Biochem. 2012;363(1-2):119-28.

43. Niculescu 3rd AB, Chen X, Smeets M, Hengst L, Prives C, Reed SI. Effects of p21(Cip1/Waf1) at both the G1/S and the G2/M cell cycle transitions: pRb is a critical determinant in blocking DNA replication and in preventing endoreduplication. Mol Cell Biol. 1998;18(1):629-43.

44. Klingbeil MF, Xavier FC, Sardinha LR, Severino P, Mathor MB, Rodrigues RV Pinto Jr DS. Cytotoxic effects of mistletoe (Viscum album L.) in head and neck squamous cell carcinoma cell lines. Oncol Rep. 2013;30(5):2316-22.

45. Stacey DW. Cyclin D1 serves as a cell cycle regulatory switch in actively proliferating cells. Curr Opin Cell Biol. 2003;15(2):158-63.

46. Sauter ER, Nesbit M, Litwin S, Klein-Szanto AJ, Cheffetz S, Herlyn M. Antisense cyclin D1 induces apoptosis and tumor shrinkage in human squamous carcinomas. Cancer Res. 1999;59(19):4876-81.

47. Folkman J. What is the evidence that tumors are angiogenesis dependent? J Natl Cancer Inst. 1990;82(1):4-6.

48. Hanahan D, Weinberg RA. Hallmarks of cancer: the next generation. Cell. 2011;144(5):646-74.

49. Wen XF, Yang G, Mao W, Thornton A, Liu J, Bast Jr RC, Le XF. HER2 signaling modulates the equilibrium between pro- and antiangiogenic factors via distinct pathways: implications for HER2-targeted antibody therapy. Oncogene. 2006;25(52):6986-96.

50. Miralem T, Steinberg R, Price D, Avraham H. VEGF(165) requires extracellular matrix components to induce mitogenic effects and migratory response in breast cancer cells. Oncogene. 2001;20(39):5511-24.

51. Barr MP, Bouchier-Hayes DJ, Harmey JJ. Vascular endothelial growth factor is an autocrine survival factor for breast tumour cells under hypoxia. Int J Oncol. 2008:32(1):41-8.

52. Petit AM, Rak J, Hung MC, Rockwell P, Goldstein N, Fendly B, Kerbel RS. Neutralizing antibodies against epidermal growth factor and ErbB-2/neu receptor tyrosine kinases down-regulate vascular endothelial growth factor production by tumor cells in vitro and in vivo: angiogenic implications for signal transduction therapy of solid tumors. Am J Pathol. 1997;151(6):1523-30.

53. Duong Van Huyen JP, Bayry J, Delignat S, Gaston AT, Michel O, Bruneval P, Kazatchkine MD, Nicoletti A, Kaveri SV. Induction of apoptosis of endothelial cells by Viscum album: a role for anti-tumoral properties of mistletoe lectins. Mol Med. 2002:8(10):600-6.

54. Podlech O, Harter PN, Mittelbronn M, Poschel S, Naumann U. Fermented mistletoe extract as a multimodal antitumoral agent in gliomas. Evid Based Complement Alternat Med. 2012;2012:501796.

55. Nahta R. Molecular Mechanisms of Trastuzumab-Based Treatment in HER2Overexpressing Breast Cancer. ISRN Oncol. 2012;2012:428062.

56. Mohsin SK, Weiss HL, Gutierrez MC, Chamness GC, Schiff R, Digiovanna MP, Wang CX, Hilsenbeck SG, Osborne CK, Allred DC, et al. Neoadjuvant trastuzumab induces apoptosis in primary breast cancers. J Clin Oncol. 2005; 23(11):2460-8.

\section{Submit your next manuscript to BioMed Central and we will help you at every step:}

- We accept pre-submission inquiries

- Our selector tool helps you to find the most relevant journal

- We provide round the clock customer support

- Convenient online submission

- Thorough peer review

- Inclusion in PubMed and all major indexing services

- Maximum visibility for your research

Submit your manuscript at www.biomedcentral.com/submit

) Biomed Central 